\title{
THE NATURAL HISTORY OF ISOLATED PULMONARY STENOSIS
}

\author{
BY
}

\author{
J. TINKER, G. HOWITT, P. MARKMAN, AND E. G. WADE \\ From the University Department of Cardiology, Manchester Royal Infirmary
}

Received April 20, 1964

The natural history of isolated pulmonary stenosis is largely unknown. Knowledge of this subject has been gained mostly from studying groups of patients of different ages, or from necropsy records, procedures clearly less satisfactory than following up individual cases. Only two authors have reported follow-up studies; Barritt (1954) observed 33 cases ( 8 have been catheterized) over periods of 5 to 21 years, and Fabricius (1959) followed up 47 of 75 fully-documented cases for periods of between 2 and 10 years, but in both series the patients were mainly children. The advent of successful surgical treatment has made such studies more difficult to pursue.

In this paper we present the findings in 75 cases of isolated pulmonary stenosis with special reference to 59 who have been observed for periods ranging from 2 to 23 years.

\section{SuBJECTS AND METHODS}

The records were examined of all patients who have attended the University Department of Cardiology, Manchester Royal Infirmary, during the past 23 years, in whom a diagnosis of isolated pulmonary stenosis was made. We were able to trace all patients in whom this diagnosis seemed likely from a study of the case notes; many had been attending at regular intervals and 24 had undergone surgical treatment. One patient diagnosed clinically died in 1952 and some died as a result of operation; all the remainder who had not been seen in the last 2 years were recalled and re-examined.

Cardiac catheterization was performed in 59 of the 75 patients; those not investigated by catheterization were only included in the series if a confident clinical diagnosis could be made. In all except one, who probably had associated aortic stenosis, pulmonary stenosis was the only lesion present. None were clinicially cyanosed. The stenosis was valvular in all except 4 patients where it was due to a localized subvalvular obstruction. Repeat catheterization after an interval of six to eight years was carried out in 3 patients.

Patients were classified into mild, moderate, and severe cases according to Wood's criteria (1956). Those subjected to cardiac catheterization were graded according to the height of the right ventricular pressure, mild cases having pressures of $30-50 \mathrm{~mm}$. $\mathrm{Hg}$, moderate between 50 and $100 \mathrm{~mm}$. $\mathrm{Hg}$, and severe over 100 $\mathrm{mm}$. Hg. Those not catheterized were graded on a combination of clinical, radiological, and electrocardiographic data as suggested by Wood, and which correlate closely with the hæmodynamic changes.

The clinical, electrocardiographic, and radiological findings at the first and subsequent attendances were noted and compared. For the purposes of this study, the period of follow-up of surgical cases ended at the time of operation. Effort tolerance was graded according to the nomenclature adopted by the New York Heart Association (1953).

The electrocardiograms were classified as follows:

Grade I: normal.

Grade II: (i) mean frontal axis of $+90^{\circ}$ to $+110^{\circ}$ and/or

(ii) $R / S$ or $R^{\prime} S$ ratio in lead $V 1$ greater than 1.0 with $R$ or $R^{\prime}$ less than 0.5 millivolts. 
Grade III (Milnor, 1957): the duration of the QRS complex less than 0.12 sec. with, in addition,

(i) mean frontal plane axis from $+110^{\circ}$ to $\pm 180^{\circ}$ or $-91^{\circ}$ to $\pm 180^{\circ}$, and/or

(ii) $R / S$ or $R^{\prime} S$ ratio in $V 1$ greater than 1.0 with $R$ or $R^{\prime}$ greater than 0.5 millivolts.

As part of a separate study (Howitt, 1963) the effect of pregnancy was investigated in 29 of these patients, and excercise studies using a double lumen catheter were carried out in 20 patients in this series.

\section{RESULTS}

Mild Pulmonary Stenosis. There were 16 patients with mild pulmonary stenosis and 9 were investigated by cardiac catheterization. The RV systolic pressure ranged from 28 to $42 \mathrm{~mm}$. $\mathrm{Hg}$. The age when last seen and duration of follow-up are shown in Fig. 1. Twelve were observed for periods between 2 and 17 years.

When first seen all were in functional Grade I with typical signs of mild pulmonary stenosis; the cardiothoracic ratios were normal. The electrocardiograms were Grade I in 13 and Grade II in 2 patients. In the remaining patient who had Grade III electrocardiographic changes the RV pressure at cardiac catheterization was $28 \mathrm{~mm}$. $\mathrm{Hg}$.

Over the period of observation there was no change in the symptoms or signs and the cardiothoracic ratios remained normal. In no instance was there any significant change in the electrocardiogram. One patient, observed for 23 years, had a posterior myocardial infarction at the age of 54. There were no deaths.

Moderate Pulmonary Stenosis. There were 22 patients with moderate pulmonary stenosis. Cardiac catheterization was performed in 16 and the right ventricular systolic pressures ranged from $55-93 \mathrm{~mm}$. Hg. A second catheterization was performed in 3 .

The age at last examination and the duration of follow-up are shown in Fig. 2. Eighteen patients were followed up for 2 or more years.

Clinical Features. When first seen effort tolerance in 21 patients was Grade I, and in 2, aged 44 and 49 years, it was Grade II. All had physical signs consistent with moderate pulmonary stenosis. There was no change in the symptoms or signs over the period of observation.

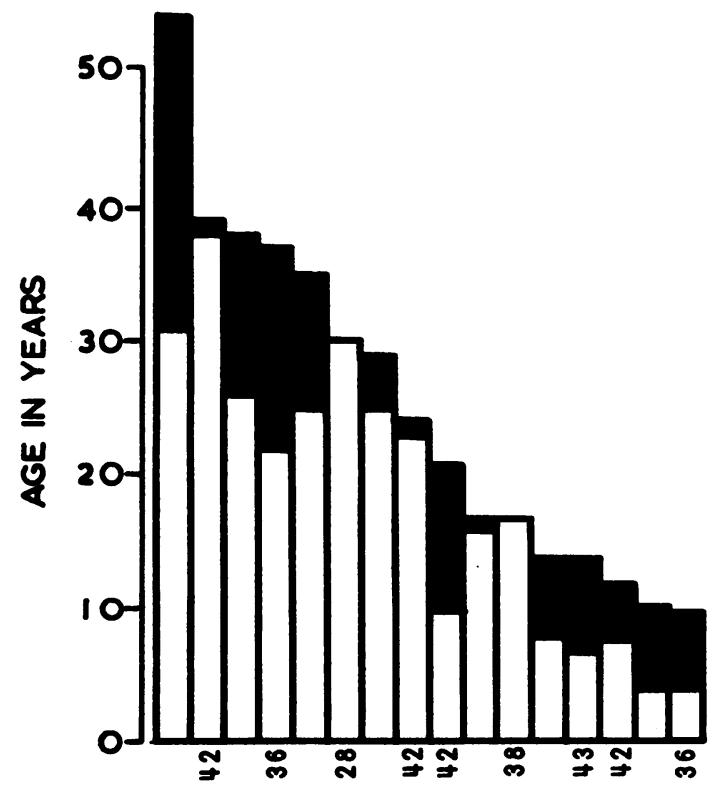

FIG. 1.-Mild pulmonary stenosis in 16 patients. Each patient is represented by a column, with age last seen (vertical axis), period of observation or follow-up by the authors (solid black), and right ventricular systolic pressure in $\mathrm{mm}$. $\mathrm{Hg}$ at cardiac catheterization in 9 patients (horizontal axis). 


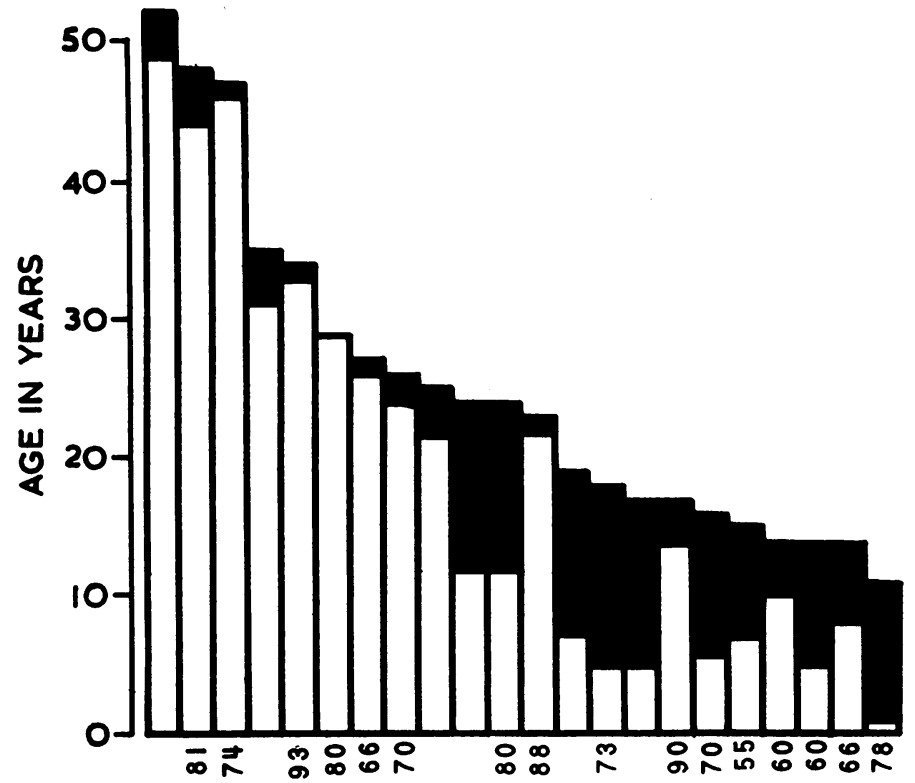

Fig. 2.-Moderate pulmonary stenosis in 22 patients. Each patient is represented by a column, with age last seen (vertical axis), period of follow-up (solid black), and right ventricular systolic pressure in $\mathrm{mm}$. $\mathrm{Hg}$ at cardiac catheterization in 16 patients (horizontal axis).

Electrocardiograms. The electrocardiograms were Grade I in 2 patients, Grade II in 6, and Grade III in 14 patients. In no instance did T wave inversion extend beyond lead V2. The electrical axis remained unchanged in 14 instances, decreased by $5^{\circ}-30^{\circ}$ in 5 , and increased by $10^{\circ}-20^{\circ}$ in 4 . There were minor changes in the RS ratios in the præcordial leads in some cases, which could be accounted for by a change in heart or electrode position and were not regarded as sufficient evidence for or against the development of right ventricular hypertrophy.

Chest Radiographs. In all except one the cardiothoracic ratio was below 0.5 initially and remained normal over the period of observation. In the remaining patient, it was 0.53 at the age of 5 years and 0.45 at 15 years.

Repeat Catheterization. Cardiac catheterization was repeated in 3 patients over a period when considerable growth occurred. Their age, height, and weight, and the hæmodynamic data, are shown in Table I.

TABLE I

Repeat Catheterization in 3 Patients with Moderate Pulmonary Stenosis

\begin{tabular}{|c|c|c|c|c|c|c|c|c|c|c|c|c|}
\hline \multirow[t]{2}{*}{ Sex } & \multirow[t]{2}{*}{ Date } & \multirow[t]{2}{*}{$\begin{array}{l}\text { Age } \\
\text { (yr.) }\end{array}$} & \multirow[t]{2}{*}{$\begin{array}{l}\text { Height } \\
\text { (cm.) }\end{array}$} & \multirow[t]{2}{*}{$\begin{array}{l}\text { Weight } \\
\text { (kg.) }\end{array}$} & \multicolumn{3}{|c|}{$\begin{array}{l}\text { Cardiac catheterization } \\
(\mathrm{mm} . \mathrm{Hg})\end{array}$} & \multirow{2}{*}{$\begin{array}{c}\text { Cardio- } \\
\text { thoracic } \\
\text { ratio }\end{array}$} & \multicolumn{4}{|c|}{ Electrocardiogram } \\
\hline & & & & & $\begin{array}{l}\text { RV } \\
\text { systolic } \\
\text { pressure }\end{array}$ & $\begin{array}{c}\text { PA } \\
\text { pressure }\end{array}$ & $\begin{array}{c}\text { Systolic } \\
\text { gradient } \\
(\mathrm{mm} . \\
\mathrm{Hg})\end{array}$ & & Axis & $\begin{array}{c}\mathbf{R} / \mathrm{S} \\
\mathrm{V} 1\end{array}$ & $\begin{array}{l}\mathrm{R} / \mathrm{S} \\
\mathrm{V} 6\end{array}$ & $\frac{T}{V 1-6}$ \\
\hline $\mathbf{M}$ & $\begin{array}{l}26.7 .55 \\
15.11 .62\end{array}$ & 10 & 180 & $\begin{array}{l}38 \cdot 5 \\
69\end{array}$ & 72 & $\begin{array}{l}16 / 12 \\
12 / 7\end{array}$ & 61 & 0.47 & $\begin{array}{l}+152^{\circ} \\
+151^{\circ}\end{array}$ & $\begin{array}{l}5 \\
1\end{array}$ & 1 & $\begin{array}{c}\text { Inverted } \\
\text { V1-2 } \\
\text { Upright }\end{array}$ \\
\hline$F$ & $\begin{array}{l}14.1 .55 \\
11.9 .62\end{array}$ & $\begin{array}{r}9 \\
16\end{array}$ & $\overline{154}$ & $\begin{array}{l}27 \cdot 6 \\
47 \cdot 6\end{array}$ & $\begin{array}{l}70 \\
46\end{array}$ & $\begin{array}{l}19 / 11 \\
15 / 5\end{array}$ & $\begin{array}{l}51 \\
31\end{array}$ & $\begin{array}{l}0.42 \\
0.42\end{array}$ & $\begin{array}{l}+90^{\circ} \\
+101^{\circ}\end{array}$ & $\frac{1 \cdot 2}{2}$ & $\begin{array}{l}5 \\
1 \cdot 25\end{array}$ & $\begin{array}{l}\text { Upright } \\
\text { Upright }\end{array}$ \\
\hline $\mathbf{F}$ & $\begin{array}{r}20.8 .57 \\
3.1 .63\end{array}$ & $\begin{array}{r}8 \\
14\end{array}$ & $\begin{array}{l}134 \\
160\end{array}$ & $\begin{array}{l}29 \\
52 \cdot 6\end{array}$ & $\begin{array}{l}66 \\
58\end{array}$ & $\begin{array}{l}13 / 6 \\
12 / 8\end{array}$ & $\begin{array}{l}53 \\
46\end{array}$ & $\begin{array}{l}0.42 \\
0.38\end{array}$ & $\begin{array}{l}+125^{\circ} \\
+120^{\circ}\end{array}$ & $\begin{array}{l}4 \\
2\end{array}$ & $\begin{array}{l}2 \\
1 \cdot 33\end{array}$ & $\begin{array}{l}\text { Upright } \\
\text { Upright }\end{array}$ \\
\hline
\end{tabular}




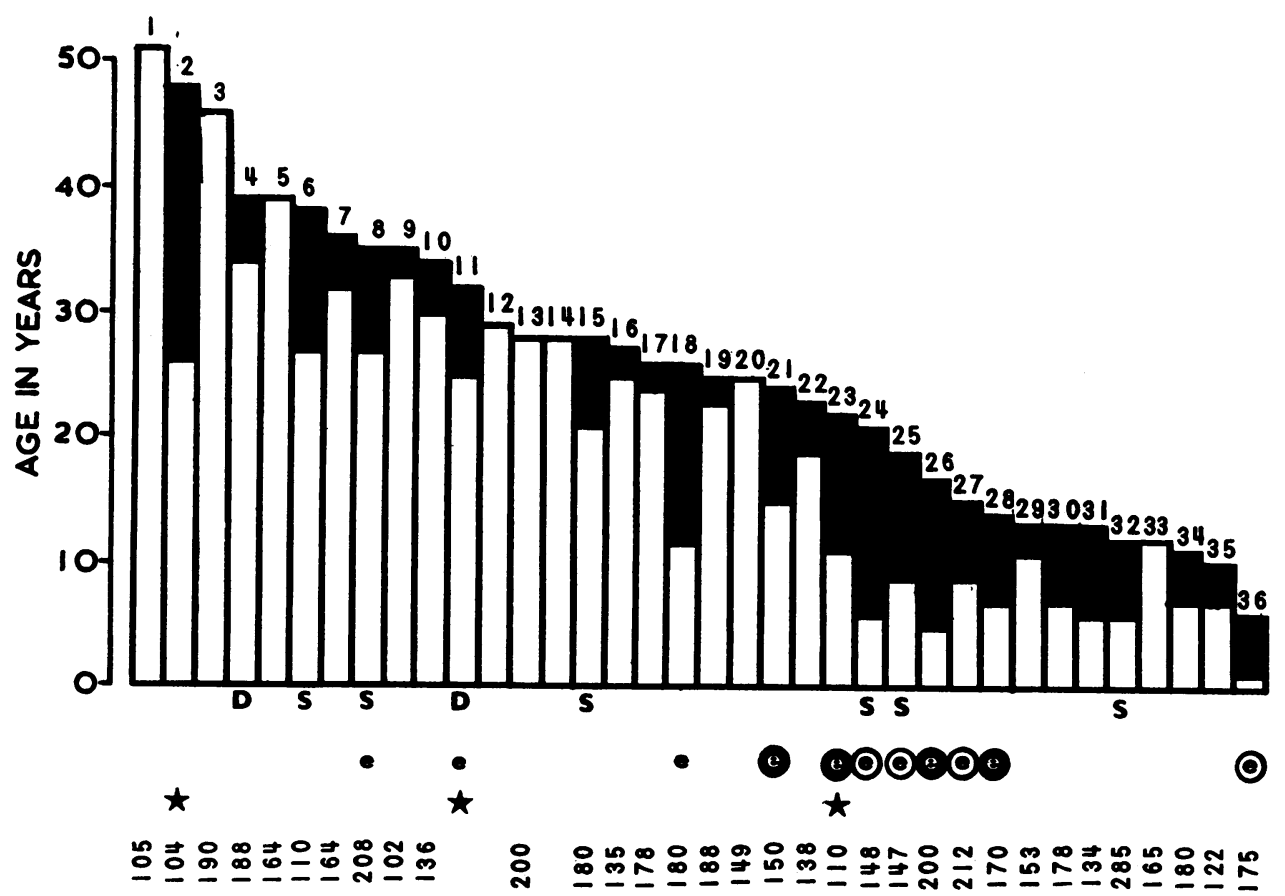

FIG. 3.- Severe pulmonary stenosis in 36 patients. Each patient is represented by a column, with age last seen (vertical axis), period of follow-up (solid black), and right ventricular systolic pressure in $\mathrm{mm}$. Hg at cardiac catherization in 33 patients (lowest horizontal axis). The numbers above each column are case numbers, and changes in symptoms, electrocardiograms, or cardiothoracic ratios during the observation period are indicated by the following symbols:

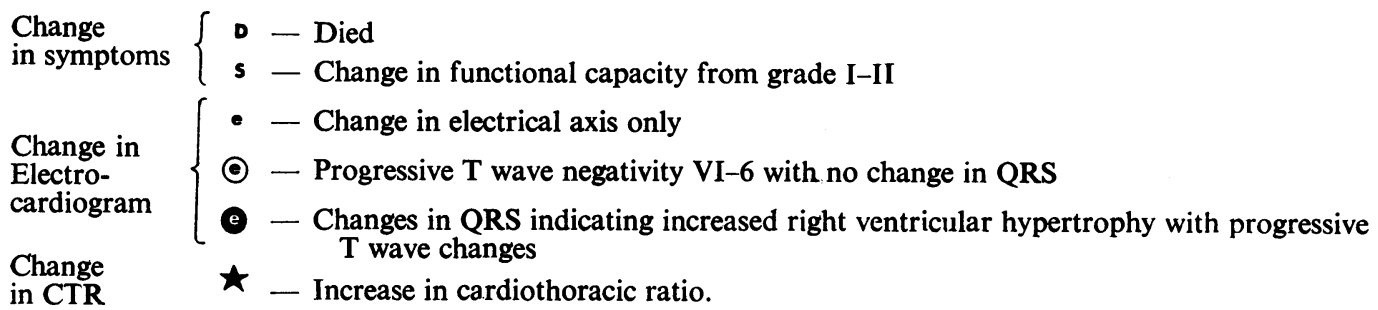

In two instances the right ventricular pressure and systolic gradient across the pulmonary valve were not significantly different on the two occasions, but in the third case the right ventricular pressure decreased by 34 per cent and the pulmonary artery to right ventricular systolic gradient by 39 per cent.

Severe Pulmonary Stenosis. There were 36 patients with severe pulmonary stenosis. The diagnosis was proved by cardiac catheterization in 33 instances, the right ventricular pressures ranged from 102-285 mm. Hg. The age at last examination and duration of follow-up are shown in Fig. 3. 28 were observed over a period of two years or more and 27 of these were catheterized. The functional capacity, electrocardiographic findings, and cardiothoracic ratios over the period of observation and the hæmodynamic data are given in Table II and Fig. 3.

Functional Capacity. Effort tolerance at the time they were last seen is shown in Table III.

Relatively more of the older patients had effort intolerance but, apart from one of the two fatal cases, none were severely disabled or showed clinical evidence of right heart failure. 
TABLE II

Patients with Severe Pulmonary Stenosis Showing Period of Follow-up, Hemodynamic Data, and Changes in Functional Capacity, Electrocardiogram, aND Cardiothoracic Ratio

\begin{tabular}{|c|c|c|c|c|c|c|c|c|c|c|c|}
\hline \multirow{3}{*}{$\begin{array}{l}\text { Case } \\
\text { No. }\end{array}$} & \multirow{3}{*}{$\begin{array}{l}\text { Age } \\
\text { (yr.) }\end{array}$} & \multirow{3}{*}{$\begin{array}{c}\text { Functional } \\
\text { capacity } \\
\text { (grade) }\end{array}$} & \multicolumn{5}{|c|}{ Electrocardiogram } & \multirow{3}{*}{$\begin{array}{c}\text { Cardio- } \\
\text { thoracic } \\
\text { ratio }\end{array}$} & \multicolumn{3}{|c|}{ Catheterization } \\
\hline & & & \multirow{2}{*}{$\begin{array}{c}\text { Elect. } \\
\text { axis }\end{array}$} & \multirow{2}{*}{$\begin{array}{l}\text { R/S } \\
\text { V1 }\end{array}$} & \multirow{2}{*}{$\begin{array}{c}\text { R/S } \\
\text { V6 }\end{array}$} & \multicolumn{2}{|c|}{$\mathrm{T}$ waves } & & \multirow{2}{*}{$\begin{array}{l}\text { Age } \\
\text { (yr.) }\end{array}$} & \multirow{2}{*}{$\begin{array}{c}\text { RV } \\
\text { systolic } \\
\text { pressure } \\
\text { (mm. Hg) }\end{array}$} & \multirow{2}{*}{$\begin{array}{l}\text { Gradient } \\
(\mathrm{mm} . \mathbf{H g})\end{array}$} \\
\hline & & & & & & Inverted & Biphasic & & & & \\
\hline 1 & 51 & I & 124 & 0.2 & 3 & V1-3 & - & 0.55 & 51 & 105 & 82 \\
\hline & $\{26$ & I & 114 & - & - & - & - & 0.49 & - & & \\
\hline 2 & $\{48$ & I & 114 & 0.2 & 1.6 & V1 & - & 054 & 48 & 104 & 82 \\
\hline 3 & 46 & I & 100 & 7 & 0.7 & V1-5 & - & 0.45 & 46 & 190 & 165 \\
\hline 4 & $\left\{\begin{array}{l}34 \\
39\end{array}\right.$ & II & 163 & $3 \cdot 4$ & 0.44 & V1-5 & - & 0.52 & 34 & 188 & 174 \\
\hline 5 & $\begin{array}{r}39 \\
39\end{array}$ & $\underset{\text { I }}{\text { Died }}$ & $\overline{141}$ & 14 & $1 \overline{1 \cdot 5}$ & $\overline{v 1-3}$ & 三 & $\overline{0.54}$ & $\overline{39}$ & $\overline{164}$ & $\overline{150}$ \\
\hline 6 & $\{27$ & I & 93 & 9 & 2 & V1 & - & 0.51 & 38 & 110 & 99 \\
\hline & 38 & II & $\begin{array}{r}93 \\
150\end{array}$ & 10 & 2 & V1 & $\overline{-1}$ & 0.51 & - & & - \\
\hline 7 & $\left\{\begin{array}{l}32 \\
36\end{array}\right.$ & $\begin{array}{l}\text { II } \\
\text { II }\end{array}$ & $\begin{array}{l}150 \\
150\end{array}$ & $\begin{array}{l}3 \cdot 5 \\
3.5\end{array}$ & $\begin{array}{l}4 \cdot 2 \\
4 \cdot 2\end{array}$ & V1 & V2-3 & 0.5 & 36 & 164 & 150 \\
\hline 8 & 27 & II & $\begin{array}{l}130 \\
135\end{array}$ & 10 & $\begin{array}{l}4 \cdot 2 \\
2\end{array}$ & $\begin{array}{l}\text { V1 } \\
\text { V1-4 }\end{array}$ & $\sqrt{2-3}$ & $\begin{array}{l}0.5 \\
0.49\end{array}$ & $\overline{35}$ & $\overline{208}$ & $\overline{200}$ \\
\hline 8 & 35 & II & 105 & 10 & 2 & V1-4 & - & 0.49 & & & 200 \\
\hline 9 & $\{33$ & I & 119 & 7 & 0.68 & V1 & V2 & 0.43 & 34 & 102 & 90 \\
\hline & 35 & I & 119 & 7 & 0.68 & V1 & V2 & 0.43 & $\overline{30}$ & $\overline{10 r}$ & $\overline{107}$ \\
\hline 10 & $\left\{\begin{array}{l}30 \\
34\end{array}\right.$ & II & 156 & 13 & 1 & V1-4 & - & 0.55 & 30 & 136 & 127 \\
\hline & $\begin{array}{l}34 \\
25\end{array}$ & $\begin{array}{l}\text { II } \\
\text { I }\end{array}$ & $\begin{array}{l}156 \\
116\end{array}$ & 13 & 1 & V1-4 & E & $\begin{array}{l}0.55 \\
0.4\end{array}$ & 二 & - & 二 \\
\hline 11 & 30 & II & 124 & 8 & 3 & $\mathrm{~V} 1$ & V2-3 & 0.7 & - & $\overline{-}$ & - \\
\hline 12 & $\begin{array}{l}32 \\
29\end{array}$ & $\begin{array}{c}\text { Died } \\
\text { I }\end{array}$ & & 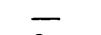 & - & & - & & - & - & - \\
\hline 13 & $\begin{array}{l}29 \\
28\end{array}$ & II & $\begin{array}{l}180 \\
143\end{array}$ & 8 & $0 \cdot 17$ & $\begin{array}{l}\text { V1 } \\
\text { V1 }\end{array}$ & - & $\begin{array}{l}0.5 \\
0.52\end{array}$ & $\overline{27}$ & $\overline{200}$ & - \\
\hline 14 & 28 & II & $\begin{array}{l}143 \\
127\end{array}$ & $\begin{array}{r}10 \\
8\end{array}$ & 0.6 & V1 & E & $\begin{array}{l}0.52 \\
0.51\end{array}$ & 21 & 200 & 二 \\
\hline 15 & $\left\{\begin{array}{l}21 \\
28\end{array}\right.$ & I & 109 & 15 & 10 & V1-6 & - & - & 22 & 240 & 206 \\
\hline & 28 & $\begin{array}{l}\text { II } \\
\text { II }\end{array}$ & 109 & 15 & 10 & V1-6 & - & 0.71 & 07 & $\overline{105}$ & \\
\hline 16 & $\left\{\begin{array}{l}25 \\
27\end{array}\right.$ & $\begin{array}{l}\text { II } \\
\text { II }\end{array}$ & $\begin{array}{l}90 \\
90\end{array}$ & $\begin{array}{l}4 \\
4\end{array}$ & $\begin{array}{l}1.2 \\
1.2\end{array}$ & $\begin{array}{l}\text { V1-5 } \\
\text { V1-5 }\end{array}$ & 二 & $\begin{array}{l}0.61 \\
0.61\end{array}$ & 27 & 135 & 123 \\
\hline 17 & 24 & I & 123 & 8 & 3 & V1-4 & V5-6 & 0.5 & $\overline{24}$ & $\overline{178}$ & $\overline{168}$ \\
\hline 17 & $\{26$ & I & 123 & 8 & 3 & V1-4 & V5-6 & 0.5 & - & . & - \\
\hline 18 & $\{11$ & I & 112 & 14 & $3 \cdot 5$ & V1-5 & - & 0.5 & 26 & 180 & 158 \\
\hline & $\begin{array}{l}26 \\
23\end{array}$ & I & 97 & 9 & $3 \cdot 3$ & V1-5 & - & 0.5 & $\overline{0 F}$ & 100 & - \\
\hline 19 & $\left\{\begin{array}{l}23 \\
25\end{array}\right.$ & II & 90 & 10 & $2 \cdot 3$ & V1-4 & - & 0.52 & 25 & 188 & - \\
\hline 20 & $\begin{array}{l}25 \\
25\end{array}$ & II & $\begin{array}{r}90 \\
104\end{array}$ & 10 & $2 \cdot 3$ & V1-4 & $\overline{v 2}$ & $\begin{array}{l}0.52 \\
0.5\end{array}$ & $\overline{25}$ & $\overline{149}$ & $\overrightarrow{139}$ \\
\hline 21 & $\{15$ & II & 113 & $\begin{array}{l}6 \\
1.65\end{array}$ & $\begin{array}{l}1.5 \\
0.1\end{array}$ & $\begin{array}{l}\text { V1 } \\
\text { V1 }\end{array}$ & V2 & $\begin{array}{l}0.5 \\
0.47\end{array}$ & 21 & 150 & $\begin{array}{l}139 \\
134\end{array}$ \\
\hline & 24 & II & 113 & 10 & $0 \cdot 1$ & V1-3 & - & 0.47 & & & 134 \\
\hline 22 & $\left\{\begin{array}{l}19 \\
23\end{array}\right.$ & II & 103 & 5 & 1.63 & V1-6 & - & 0.5 & 23 & 138 & 127 \\
\hline 23 & $\{12$ & I & 133 & 0.42 & 1 & - & V1 & 0.38 & 14 & 110 & 100 \\
\hline & 22 & I & 133 & 1.33 & 1 & V1-4 & & 0.43 & & & \\
\hline 24 & $\left\{\begin{array}{r}6 \\
21\end{array}\right.$ & I & 135 & $3 \cdot 6$ & 1.5 & - & V1 & 0.5 & 21 & 148 & 138 \\
\hline & \}$_{9}^{21}$ & $\begin{array}{l}\text { II } \\
\text { I }\end{array}$ & $\begin{array}{l}132 \\
156\end{array}$ & $2 \cdot 5$ & $\begin{array}{l}1.5 \\
0.69\end{array}$ & V1-4 & $\overline{v 1}$ & $\begin{array}{l}0.48 \\
0.37\end{array}$ & $\overline{18}$ & $\overline{147}$ & 121 \\
\hline 25 & 19 & II & $\begin{array}{l}150 \\
153\end{array}$ & $\begin{array}{l}16 \\
18\end{array}$ & $\begin{array}{l}0.69 \\
1\end{array}$ & & v1 & 0.37 & 18 & 147 & 134 \\
\hline 26 & 5 & I & 96 & 7 & $2 \cdot 8$ & V1-2 & - & & 14 & 200 & 180 \\
\hline & $\begin{array}{l}17 \\
9\end{array}$ & I & 102 & 36 & $3 \cdot 7$ & V1-6 & - & $0 \cdot 5$ & $\overline{15}$ & $\overline{212}$ & $\overline{184}$ \\
\hline 27 & $\left\{\begin{array}{r}9 \\
15\end{array}\right.$ & $\begin{array}{l}\text { I } \\
\text { I }\end{array}$ & $\begin{array}{l}136 \\
182\end{array}$ & 12 & 1 & $\begin{array}{l}\text { V1-4 } \\
\text { V1-6 }\end{array}$ & & $\begin{array}{l}0.54 \\
0.54\end{array}$ & 15 & 212 & 184 \\
\hline 28 & 7 & I & 140 & 1.6 & 1.4 & - & V1-3 & 0.5 & 12 & 170 & $\overline{161}$ \\
\hline 20 & 14 & I & 140 & 12 & 1 & - & V1-3 & 0.5 & $\overline{10}$ & & \\
\hline 29 & $\left\{\begin{array}{l}11 \\
13\end{array}\right.$ & I & 145 & 12 & - & $\overline{11}$ & - & 0.46 & 13 & 153 & 137 \\
\hline 30 & 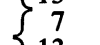 & I & 145 & 12 & 1 & v1 & 二 & $\begin{array}{c}0.46 \\
-\end{array}$ & $\overline{13}$ & 178 & 168 \\
\hline & 13 & I & 145 & 29 & $0 \cdot 13$ & V1-2 & V3-4 & 0.55 & & & \\
\hline 31 & $\left\{\begin{array}{r}6 \\
13\end{array}\right.$ & $\begin{array}{l}\text { I } \\
\text { I }\end{array}$ & $\begin{array}{l}94 \\
90\end{array}$ & $\begin{array}{l}10 \\
10\end{array}$ & $\begin{array}{l}5 \\
5\end{array}$ & $\begin{array}{l}\text { V1 } \\
\text { V1 }\end{array}$ & 二 & $\begin{array}{l}0.48 \\
0.48\end{array}$ & 13 & 134 & 126 \\
\hline 32 & 6 & I & 168 & 10 & & & 二 & 0.48 & $\overline{10}$ & $\overline{285}$ & $\overline{263}$ \\
\hline 33 & $\{12$ & II & 161 & 5 & $0 \cdot 3$ & V1-5 & - & - & - & & 200 \\
\hline 33 & 12 & II & 105 & $3 \cdot 6$ & $3 \cdot 3$ & V1-6 & $\overline{0}$ & $0 \cdot 6$ & 11 & 165 & 155 \\
\hline 34 & $\left\{\begin{array}{r}7 \\
11\end{array}\right.$ & II & 120 & 18 & 3 & V1 & V2 & 0.5 & 10 & 180 & 170 \\
\hline & 7 & II & $\begin{array}{l}120 \\
145\end{array}$ & ${ }_{0}^{18}$ & $\begin{array}{l}3 \\
0 \cdot 11\end{array}$ & $\begin{array}{l}\text { V1 } \\
\text { V1 }\end{array}$ & $\begin{array}{l}\text { V2 } \\
\text { V2 }\end{array}$ & $\begin{array}{l}0.5 \\
0.5\end{array}$ & $\overline{9}$ & $\overline{122}$ & 二 \\
\hline 35 & $\{10$ & I & 145 & 0.11 & 0.11 & V1 & V2 & 0.5 & - & 122 & 二 \\
\hline 36 & $5 / 12$ & I & 103 & 12 & 2 & V1 & $\mathrm{V} 2$ & 0.54 & 6 & 175 & 157 \\
\hline & & I & 98 & 12 & 1 & V1-2 & V3-5 & 0.54 & - & & \\
\hline
\end{tabular}


TABLE III

Severe Pulmonary Stenosis: Functional Capacity at Time of Last Attendance

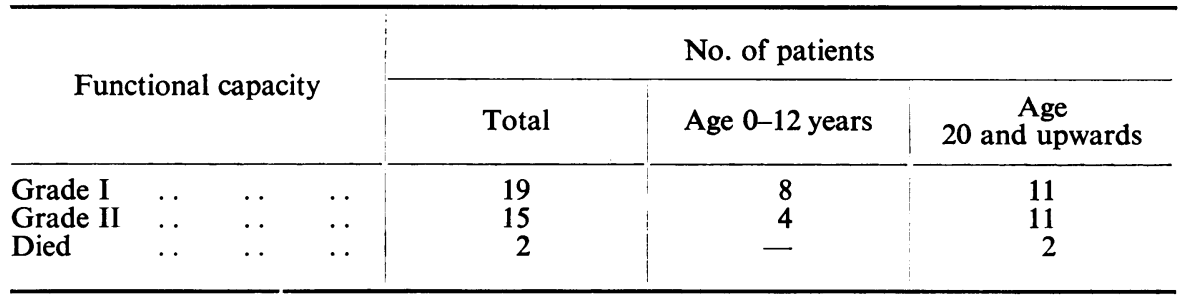

Of the 28 patients observed for two years or more, 6 changed from Grade I to II and 2 died. Only 2 of these 8 who deteriorated clinically did so before the age of 20 . There appeared to be no correlation between functional capacity or change in functional capacity and the right ventricular pressure in this group.

Death from heart disease occurred in 2 instances.

Case 11 (Table II, Fig. 3) was first seen at the age of 25 years in her first pregnancy. She had no cardiac symptoms and remained well throughout pregnancy. Three months post partum the cardiothoracic ratio was 0.4 and the electrocardiogram showed abnormal right axis deviation (standard limb leads only were taken). She next attended 5 years later, with a 12-month history of progressive dyspnœa; a pulmonary diastolic murmur was now audible and there was evidence of right heart failure. The cardiothoracic ratio was 0.7 and the electrocardiogram showed severe right ventricular hypertrophy, the electrical axis had moved to the right. She died shortly afterwards. Although there was no positive evidence it seemed possible that her rapid deterioration was due to bacterial endocarditis.

Case 4 (Table II, Fig. 3) was first seen at the age of 34 . Her functional capacity was Grade II and the right ventricular pressure at cardiac catheterization was $188 \mathrm{~mm}$. Hg. The cardiothoracic ratio was 0.52. Five years later when walking in the street she died suddenly; there was no necropsy. Her general practitioner, who had seen her the previous day, informed us that up to the time of death her effort tolerance had not deteriorated and she was leading an active life.
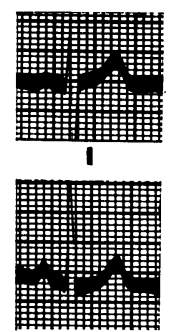

II

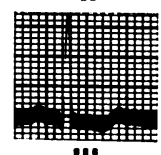

III

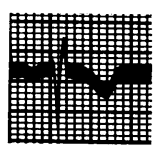

$\mathbf{R}$

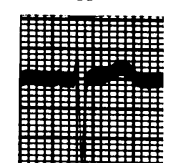

$\mathbf{L}$

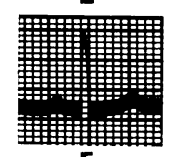

F

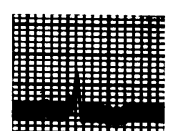

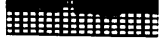

V1

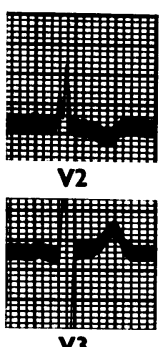

A

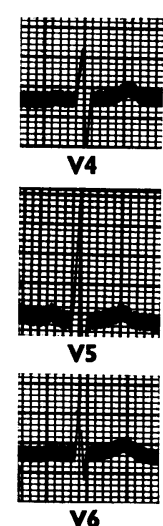

V6

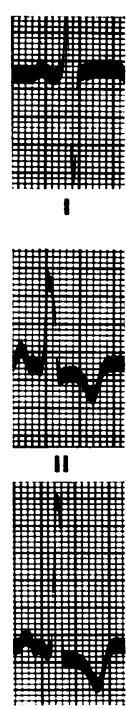

III
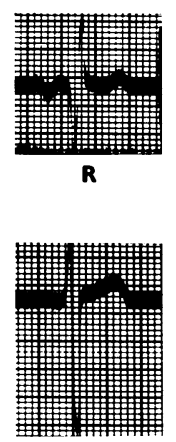

L

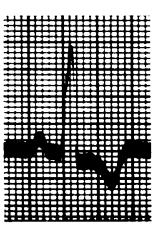

$\mathbf{F}$
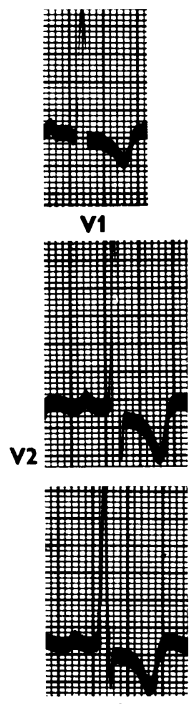

$\mathbf{V}$

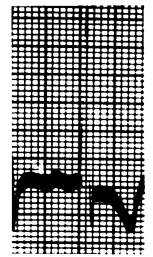

V4

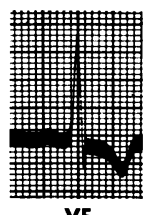

V5

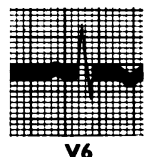
the increase in amplitude of the $R$ waves in $V 1$ and the deeply inverted $T$ waves extending across to V6 in the second record. 
Electrocardiograms. The R/S ratios in V1 and $\mathrm{V} 6$ and the extent of the $\mathrm{T}$ wave changes in the præcordial leads were compared over the period of observation. The patients who showed significant change in these parameters are indicated in Fig. 3. Three patients showed only a change in axis, in one the degree of right axis deviation increased and in the other 2 it decreased. It is noteworthy that all 4 who exhibited both a significant change in the R/S ratios and V1 and V6 and T wave changes, and 3 of the 4 who developed only $T$ wave changes, did so during the period of maximum growth. In spite of this, in the group as a whole, $T$ wave changes in the præcordial series were not more striking in the older patients. The electrocardiograms of a patient (Case 26, Fig. 3, Table II) who developed considerable increase in right ventricular hypertrophy are shown in Fig. 4.

Chest Radiographs. In only 3 patients did the cardiothoracic ratio increase over the period of observation (Fig. 3), and in 2 of these it became abnormal. In one (Case 2) the patient was followed up for 23 years, and the other (Case 11), referred to above, died. In the third patient (Case 23) the cardiothoracic ratio increased but was only 0.43 when he was last seen. The cardiothoracic ratio did not bear any definite relation to age or to the height of the right ventricular pressure.

\section{Discussion}

Fontana and Edwards (1962) collected 123 reported cases of isolated pulmonary stenosis proved at necropsy, the median age at death being 20 years. They stated that about 50 per cent of these patients failed to achieve adult life and that those with a patent foramen ovale (half their series) tended to die earlier than those with an intact atrial septum. The leading cause of death was cardiac failure; there were $35(28 \%)$ deaths from this cause; median age 22 years.

These figures suggest that patients with pulmonary stenosis die young, but Fabricius (1959), also reviewing previously reported necropsy series, showed that the prognosis was not so poor as seemed at first sight. He analysed 77 reported necropsy cases with an intact atrial septum and found that, of the 75 instances where the age at death was stated, 29 per cent were over 40 . If 24 patients dying of a non-cardiac disorder before this age were excluded, 43 per cent of patients reached the age of 40 or over. However, necropsy studies must of necessity be based on a selected series of patients drawn from a "pool" of unknown size and studies of living patients may present a different picture. Survival up to or beyond the age of 70 has been reported by a number of authors (Ascarelli, 1932; Bret, 1936; Bonnamour and Dumarest, 1940; White, Hurst, and Fennell, 1950; Genovese and Rosenbaum, 1951; Wild et al., 1957). All authorities agree that the prognosis is poor in severe and good in mild cases; there is less certainty about the prognosis in moderate cases. Keith, Rowe, and Vlad (1958) state that it is excellent, Wood (1956) has stated that they are unlikely to develop heart failure, and Dow et al. (1950) suggest that congestive failure is the natural sequel in all but the mildest cases. Wild et al. (1957) consider that they will probably be able to lead a reasonably active life until after middle life. Of the mild and moderate cases which we followed up there were no deaths and no evidence of deterioration clinically or as reflected in the cardiograms or chest radiographs. Barritt (1954) and Fabricius (1959) in their follow-up studies found no definite evidence of deterioration in these groups of patients.

Two of our patients with severe stenosis died during the period of observation, one of possible subacute bacterial endocarditis at the age of 30 years and one suddenly at 39 years. Six others ( 2 in each decade from the second to the fourth) experienced some diminution in effort tolerance unassociated with any change in physical signs or evidence of congestive heart failure. A significant increase in the cardiothoracic ratio occurred in one fatal case and in two others who did not deteriorate clinically.

Deterioration may be due to one of three factors; the stenosis may become relatively or actually more severe; infundibular obstruction may develop; or the compensatory hypertrophy of the right ventricle may break down. Increasing severity of the stenosis is most likely to be relative and due to disproportionate physical growth; after growth has ceased the only likely cause of further narrowing would be fibrosis or bland vegetations on the cusps (White et al., 1950; Campbell and Missen, 
1959). It must be emphasized that slight changes in valve orifice size will be more critical in severe cases and will be less easily detectable in mild or moderate cases. Three of our patients were re-catheterized after a period of rapid growth; in two the transvalvular gradient was unchanged and in the third it was reduced. The significance of these observations is, however, weakened by the fact that cardiac outputs were not estimated, and clearly the right ventricular systolic pressure in pulmonary stenosis is a function not only of the valve size but also of stroke volume and the duration of systole. All three had moderate stenosis and we have not had the opportunity of recatheterizing a case of severe stenosis before and after puberty. The only other serial catheterization studies are those of Fabricius (1959) who reinvestigated 12 patients; accepting a change in right ventricular pressure of more than 20 per cent as significant, he reported a rise in 3 and no change in the remainder. He did not consider the change in gradient to be related either to the age of the patient or to the time separating the two investigations. Therefore, our serial catheterization studies and those of Fabricius do not give conclusive evidence that the valvular stenosis tends to become relatively more severe during periods of rapid body growth, nor do they give any indication of the importance of hypertrophic stenosis of the outflow tract. It is a common observation at operation that the outflow tract may be hypertrophied to such an extent that some of the muscle may have to be removed to allow free egress of blood from the right ventricle, but there is no evidence that it may constitute an increased hindrance in unrelieved valvular stenosis.

Though repeat catheterization studies do not demonstrate increasing stenosis during the period of rapid body growth, a different impression is gained in the severe cases from a study of the serial cardiograms. Numerous authors, most recently Bassingthwaighte et al. (1963), have correlated the electrocardiographic changes with the severity of stenosis, and it may be assumed that increase in voltage of the $R$ wave in V1 with an increase in the R/S ratio in V1 and a decrease in V6 imply an increase in right ventricular mass. Four of our cases showed unequivocal evidence of increasing right ventricular enlargement and 3 of the cases followed up by Fabricius (1959) showed similar changes. The meaning of increasing $T$ wave negativity in the præcordial leads with no change in QRS is less certain; 4 of our patients showed these changes as did those reported by Marquis (1951) and Barritt(1954). Fabricius(1959) considers that negative $T$ waves in V4-6 are an important criterion in the diagnosis of severe stenosis, but Bassingthwaighte et al. (1963) failed to find any close correlation between $T$ wave changes extending across to the left præcordial leads and the pressure gradient. Engle et al. (1960) stated that unusual depth of the T wave inversion in the right præcordial leads was as significant as spread of $T$ wave inversion across the præcordium. Campbell (1959) thought that in most cases the $\mathrm{T}$ wave changes were due to a disturbance in myocardial function as they regressed after valvotomy and did so more quickly than changes in QRS. However, in some of his older cases the $T$ wave changes persisted, suggesting they were a manifestation of irreversible damage, presumably myocardial fibrosis. In the series of Marquis (1951) no fibrosis was present at necropsy in the cases with severe $T$ wave changes except in one, the eldest, who died at the age of 30.

All our patients who showed these electrocardiographic changes developed them before they reached the age of 20 and mostly during the period of maximum growth. No cardiographic changes occurred in patients seen initially after the age of 20 , nor did the cardiogram show any deterioration in any of the mild or moderate cases. In short, there is some evidence from the cardiograms that in 4 patients with severe pulmonary stenosis right ventricular hypertrophy did increase during periods of growth and that in 4 others, during the same period of growth, a change of uncertain nature took place in the right ventricular muscle.

All our mild, all but 2 of our moderate, and 20 of the 35 severe cases had a normal exercise tolerance, and Wood (1956) reported patients with moderate stenosis who were first class athletes. Exercise studies in pulmonary stenosis will be reported separately, but our experience indicates that cardiac output response to effort is normal in mild and moderate cases. The two ventricles are of equal thickness at birth and there seems no theoretical reason from the basic arrangement of muscle fibres or the available blood supply why, in the presence of congenital pulmonary stenosis, the right 
ventricle should not deal efficiently and indefinitely with work loads approximating to those normally borne by the left ventricle; it is perhaps significant that the prognosis is likely to be poor only in cases where right ventricular pressure exceeds normal systemic levels. It must be borne in mind that on effort the peripheral resistance tends to fall whereas the hindrance of the stenosed pulmonary valve is unaltered so that right ventricular work may increase more than left ventricular work, but there is no reason to suppose that a degree of stenosis associated with a resting right ventricular pressure below $100 \mathrm{~mm}$. $\mathrm{Hg}$ will cause an intolerable situation on effort or impose a work load on the right ventricle which cannot be borne indefinitely.

\section{SUMMARY}

Observations on the natural history of isolated pulmonary stenosis are reported, based on a study of 75 patients, 59 of whom were followed up for periods of 2 to 22 years.

Apart from one who suffered a myocardial infarction at the age of 54, there was no evidence of deterioration in 39 patients with mild or moderate pulmonary stenosis. Three with moderate stenosis were re-catheterized after intervals of 6 to 8 years; in one the right ventricular pressure and gradient across the pulmonary valve decreased considerably, and in the other two there was no change.

There were 36 patients with severe pulmonary stenosis and 28 were observed for periods of 2 years or more. Effort tolerance deteriorated from Grade I to II in 6 of these and 2 died. Four showed unequivocal evidence of increased right ventricular hypertrophy and 4 others developed isolated progressive $\mathrm{T}$ wave changes in the præcordial leads. These changes most commonly developed between the ages of 10 and 20 years. Increase in heart size occurred in only 3 cases. In these severe cases, deterioration as judged by the cardiothoracic ratio, development of electrocardiographic changes or increase in symptoms, did not appear to correlate with the height of the right ventricular systolic pressure.

We wish to thank Dr. A. Morgan Jones for permission to study cases under his care, Mr. H. McGrath and Mrs. E. Hayes for technical assistance, and Mrs. B. Boyce for secretarial assistance. One of the authors (J.T.) carried out this work while receiving a grant from the Research Grants Committee of the United Manchester Hospitals. We are grateful to the Department of Medical Illustration for the preparation of Fig. 1-4.

\section{REFERENCES}

Ascarelli, A. (1932). Intorno a un caso di ectasia aneurismatica dell'arteria polmonale. Policlinico, Sez. prat., 39, 679.

Barritt, D. W. (1954). Simple pulmonary stenosis. Brit. Heart J., 16, 381.

Bassingthwaighte, B., Parkin, T. W., DuShane, J. W., Wood, E. H., and Burchell, H. B. (1963). The electrocardiographic and hemodynamic findings in pulmonary stenosis with intact ventricular septum. Circulation, $28,893$.

Bonnamour and Dumarest (1940). Sur un cas de rétrécissement pulmonaire congénital. Lyon méd., 164, 182.

Bret, J. (1936). Le rétrécissement pulmonaire à évolution prolongée. Thesis, Lyon.

Campbell, M. (1959). Valvotomy as a curative operation for simple pulmonary stenosis. Brit. Heart J., $21,415$.

-, and Missen, G. A. K. (1959). Survival in good health until 65 years with pulmonary valvar stenosis. Guy's Hosp. Rep., 108, 390.

Dow, J. W., Levine, H. D., Elkin, M., Haynes, F. W., Hellems, H. K., Whittenberger, J. W., Ferris, B. G., Goodale, W. T., Harvey, W. P., Eppinger, E. C., and Dexter, L. (1950). Studies of congenital heart disease. IV. Uncomplicated pulmonic stenosis. Circulation, 1, 267.

Engle, M. A., Ito, T., Lukas, D. S., and Goldberg, H. P. (1960). Electrocardiographic evaluation of pulmonic stenosis. J. Pediat., 57, 171.

Fabricius, J. (1959). Isolated Pulmonary Stenosis. Munksgaard, Copenhagen.

Fontana, R. S., and Edwards, J. E. (1962). Congenital Cardiac Disease; A Review of 357 Cases Studied Pathologically. Saunders, Philadelphia and London.

Genovese, P. D., and Rosenbaum, D. (1951). Pulmonary stenosis with survival to the age of 78 years. Amer. Heart J., 41, 755.

Howitt, G. (1963). Congenital Heart Disease and Pregnancy. M.D. Thesis, Manchester University.

Keith, J. D., Rowe, R. D., and Vlad, P. (1958). Heart Disease in Infancy and Childhood. Macmillan, New York.

Marquis, R. M. (1951). Unipolar electrocardiography in pulmonary stenosis. Brit. Heart J., 13, 89. 
Milnor, W. R. (1957). Electrocardiogram and vectorcardiogram in right ventricular hypertrophy and right bundlebranch block. Circulation, 16, 348.

New York Heart Association (1953). Nomenclature and Criteria for Diagnosis of Diseases of the Heart and Blood Vessels, 5th ed., p. 82. New York.

White, P. D., Hurst, J. W., and Fennell, R. H. (1950). Survival to the age of 75 years with congenital pulmonary stenosis and patent foramen ovale. Circulation, 2, 558.

Wild, J. B. Eckstein, J. W., Van Epps, E. F., and Culbertson, J. W. (1957). Three patients with congenital pulmonic valvular stenosis surviving for more than 75 years. Amer. Heart J., 53, 393.

Wood, P. H. (1956). Diseases of the Heart and Circulation, 2nd ed. Eyre and Spottiswoode, London. 